\title{
Lipid absorption and hepatic metabolism in ruminants
}

\author{
BY DOMINIQUE BAUCHART, DOMINIQUE GRUFFAT \\ AND DENYS DURAND \\ Laboratoire Croissance et Métabolismes des Herbivores, INRA, \\ Centre de Recherches, Clermont-Ferrand-Theix, 63122 St Genès Champanelle, France
}

\section{L'absorption des lipides et le métabolisme hépatique des ruminants}

\begin{abstract}
RÉSUMÉ
Les matières grasses sont ajoutées aux rations des ruminants pour améliorer l'efficacité d'utilisation de l'énergie à des fins de production. L'intestin grêle des ruminants possède une forte capacité d'absorption des acides gras alimentaires saturés par l'action des hydrogénases bactériennes du rumen. La synthèse et la sécrétion des lipoprotéines riches en triacylglycérols (chylomicrons, VLDL) par l'intestin grêle varie avec le degré d'insaturation des chaînes grasses alimentaires. Le lent processus d'absorption des acides gras chez le veau préruminant favorise la sécrétion des lipoprotéines riches en triacylglycérols par la voie de la veine porte. La fraction protéique de ces particules lipoprotéiques est dominée, chez le bovin, par l'apoprotéine B48, forme tronquée de l'apo $B$ résultant de la modification unique post-transcriptionnelle de l'ARN messager de l'apo B. Le métabolisme hépatique des lipides des ruminants présente des particularités favorisant la formation de foie gras et le développement d'une cétoacidose nuisible à la santé et aux capacités de reproduction des animaux. Le foie possède une forte capacité d'estérification et de stockage des acides gras exogènes sous forme de triacylglycérols ou d'oxydation de ces acides gras sous forme de corps cétoniques. Les faibles capacités de synthèse de l'apo B100 et de mobilisation des triacylglycérols stockés dans le cytoplasme limitent fortement la sécrétion hépatique des triacylglycérols sous forme de VLDL. Chez les femelles en début de lactation, le développement de l'infiltration lipidique du foie n'est pas réduit par la supplémentation lipidique des rations mais plutôt par l'apport alimentaire d'acides aminés limitants (méthionine, lysine). La modulation de l'expression du gène hépatique de l'apo $B$ au cours du cycle gestation-lactation explique, en partie, le développement de l'infiltration graisseuse observée en début de lactation.
\end{abstract}

With the exception of milk substitutes in young preruminant animals, the diets of cattle contain little or no added fat. However, in the last two decades, there has been increasing interest in adding fat to the diets of growing and lactating cattle in order to increase efficiency of energy utilization for animal performance. Justifications for this approach, recently summarized by Palmquist $(1988,1994)$ and Clinquart et al. (1995), include (1) increased energy density of the diets, (2) increased availability of high-quality fats from industry, (3) improved quality of the carcass of growing-fattening cattle, (4) improved dietetic quality of fat in milk and in muscle tissues, (5) improved lactation and reproductive performance and metabolic efficiency of lactating cattle. In order to protect 
fats against desaturation within the rumen bacteria and avoid the depressive effect of dietary fat on rumen fermentation in general, modified dietary fat (encapsulated or as $\mathrm{Ca}$ soaps) is now utilized (Doreau et al. 1989).

The net energy value of fat depends on its digestibility and its effect on intermediary metabolism. In the latter respect, the liver is known to carry out central metabolic functions in various aspects of lipid and lipoprotein metabolism such as uptake, oxidation and metabolic conversion of free fatty acids, synthesis of cholesterol and phospholipids and formation and secretion of specific classes of lipoproteins. The present paper mainly concerns our work on lipoprotein secretion by the small intestine and on hepatic metabolism of lipoproteins and their regulation by dietary lipids in preruminant calves and dairy cows.

\section{LIPID ABSORPTION AND LIPOPROTEIN SECRETION BY SMALL INTESTINE}

\section{Lipid digestion in ruminants}

The general features of lipid digestion in ruminants have been reviewed by Moore $\&$ Christie (1984). Fermentation of dietary components in the rumen is associated with extensive hydrolysis of lipids and biohydrogenation of the resultant fatty acids. There is also de novo lipid synthesis by the rumen bacteria leading to saturated and transmonoene fatty acids. The particularly high efficiency of the small intestine of the ruminant in absorbing saturated fatty acids is explained by the great capacity of the predominant bile salt, taurocholate and the lysophospholipid micellar system to solubilize these fatty acids at low $\mathrm{pH}(<3 \cdot 5)$.

The intestinal absorption of dietary fatty acids in ruminant animals appeared relatively constant after meal intake. Thus, in dairy cows given a high-fat ration, plasma triacylglycerol concentration was higher than that in control cows, but did not vary significantly during the postprandial period (Bauchart et al. 1987).

The digestive system of the preruminant calf is distinct from that of the adult animal. Milk, the only dietary constituent, induces a closing reflex of the oesophageal groove, thereby allowing direct passage of ingested milk beyond the forestomachs. This circumvents modification of the chemical structure of the milk lipids. On this basis, the calf may be considered as a transient, functional non-ruminant. The coagulation of milk caseins of type kappa $(K)$ by chymosin results in the retention of dietary triacylglycerols in an insoluble clot in the abomasum for several hours. This coagulation process does not involve dietary small molecules such as lactose and peptides that are rapidly digested and absorbed as glucose and free amino acids. Utilizing electromagnetic blood-flow measurement, we have shown that in calves fed on a milk diet which curdles in the abomasum, portal blood flow rapidly increases $1 \mathrm{~h}$ after meal intake, probably in response to the intestinal absorption of glucose (Durand et al. 1988). Hyperglycaemia noted 46-90 min after intake increased plasma insulin which stimulated the degradation of plasma triacylglycerols by lipoprotein lipase (EC 3.1.1.34; LPL; Bauchart \& Levieux, 1985). This was followed by the clot formation in the abomasum decreasing portal blood flow for the next $4 \mathrm{~h}$ due to the drop in mesenteric blood flow (which constitutes $65 \%$ of the portal blood flow) following a lack of nutrient absorption during this period. The slow and progressive reduction of the clot from $5 \mathrm{~h}$ after intake restored absorption and, therefore, kept higher mesenteric and portal blood flows until the end of the 24 h period (Durand et al. 1988). 
Chylomicrons and VLDL involved in the transport of intestinal triacylglycerols were isolated by sequential ultracentrifugation. During the postprandial period, a large increase in the plasma concentrations of calf chylomicrons and VLDL was noted from $7 \mathrm{~h}$ after meal intake. Furthermore, the fatty acid composition of triacylglycerols of these particles was then representative of the dietary fatty acid composition (Bauchart \& Levieux, 1985). These results provided evidence that in the calf fed on curdled milk substitute peak lipid absorption was 5-7 $\mathrm{h}$ later than that in conventional singlestomached animals.

\section{Intestinal secretion of triacylglycerol-rich lipoproteins}

To investigate the mechanisms of synthesis and secretion of triacylglycerols by the small intestine and their subsequent metabolism in the blood we have developed techniques, using chronic catheters, for simultaneous collection of intestinal lymph and blood from the portal vein and mesenteric artery of the preruminant calf. Blood and lymph flows were measured using electromagnetic flow meters and volumetric analysis respectively during the postprandial period (Laplaud et al. 1989; Durand et al. 1990). In the preruminant calf given $120 \mathrm{~g}$ fat in a single daily meal, total intestinal production of chylomicrons amounted to $4 \mathrm{~g} / \mathrm{h}$ at peak lipid absorption (i.e. $8 \mathrm{~h}$ after intake), and 1.3 $\mathrm{g} / \mathrm{h} 8 \mathrm{~h}$ later. A similar result was observed for VLDL (Durand et al. 1990). Under these conditions, we noted a large contribution of the portal vein to intestinal triacylglycerol transport of chylomicrons (67\%) and VLDL (58\%), especially at peak lipid absorption. It is likely that, in the calf fed on a milk diet which curdles in the abomasum, the slow intestinal lipid absorption favours triacylglycerol secretion into the portal vein. This situation is similar to that of the rat given a slow duodenal infusion of fatty acids.

The rate of production of chylomicrons and VLDL by the small intestine increased with fat intake in the calf (Auboiron et al. 1994). Lipid transport in the intestinal lymph is controlled by the degree of unsaturation of dietary fatty acids absorbed by the intestine rather than by the stage of maturity of the rumen. In adult sheep fitted with a chronic catheter in the thoracic duct and maintained under normal rearing conditions, $72.6 \%$ of lymph lipids were located in the VLDL fraction of control lymph and $27.4 \%$ in the chylomicron fraction. However, after continuous $24 \mathrm{~h}$ infusion of maize oil (rich in $n-6$ polyunsaturated fatty acids (PUFA)) at $2 \mathrm{~g} / \mathrm{h}$ through a duodenal cannula, $38.5 \%$ of the lymph lipids were located in the VLDL fraction and $61.5 \%$ in the chylomicron fraction (Harrison et al. 1974). Recent work in our laboratory clearly showed that a soyabean-oilrich milk diet reduced calf plasma chylomicrons relative to a tallow-rich diet, suggesting a negative effect of dietary $n-6$ PUFA on intestinal secretion of chylomicrons (LeplaixCharlat et al. 1996). In the same work, addition of cholesterol to a tallow or soyabean-oil-rich diet $(10 \mathrm{~g} / \mathrm{kg}$ dietary DM) increased plasma concentrations of chylomicrons by 2 -fold only with the tallow-based diet. These results emphasized the complex regulation of intestinal lipid secretion by dietary fatty acids and cholesterol intake in cattle.

\section{Structural properties of lymph lipoproteins}

The hydrodynamic and physico-chemical properties of calf lymph and plasma lipoproteins were assessed by various analytical methods including analytical ultracentrifu- 
gation, gradient gel electrophoresis, affinity chromatography and electron microscopy of native lipoproteins, electrophoresis and immunoassay of their apolipoprotein moieties, and preparative chromatographic and GLC analysis of their lipid fractions (Bauchart, 1993).

Analysis of postprandial calf intestinal lymph showed that the lipoprotein spectrum was dominated by chylomicrons $(76 \%)$ and VLDL $(19 \%)$ whose particle diameters ranged from 65 to $240 \mathrm{~nm}$ and from 34 to $86 \mathrm{~nm}$ respectively. Analysis of the apolipoprotein content of these particles by SDS-PAGE clearly showed the presence of a unique isoform of apo B comparable with human apo B48 (Laplaud et al. 1990). In contrast, two different isoforms, apo B100 (molecular mass (MM) $520 \mathrm{kDa}$ ) and apo B48 (MM $265 \mathrm{kDa}$ ), were always identified in calf plasma (Bauchart et al. 1989). This finding suggested that the generation of the truncated isoform, apo B48, in calf intestine can be mediated, as in many mammalian species, by a unique post-transcriptional RNA modification. This hypothesis of apo B mRNA editing in bovine intestine was confirmed by a quantitative primer extension analysis following reverse-transcribed and polymerase chain reaction (PCR) amplified apo B mRNA (Greeve et al. 1993). The level of intestinal apo $\mathrm{B}$ mRNA editing varies according to the herbivorous species. Primer extension demonstrated almost complete editing of apo B mRNA in bovine intestine $(95 \%)$ and incomplete editing in that of sheep (40\%) and horse (73\%; Greeve et al. 1993).

Calf lymph lipoproteins with a density higher than $1.006 \mathrm{~g} / \mathrm{ml}$ mainly consisted of HDL but several populations of LDL were also identified (Laplaud et al. 1990). The particle heterogeneity in the $1.040-1.090 \mathrm{~g} / \mathrm{ml}$ density interval, noted both in intestinal lymph and blood plasma, was resolved by the use of heparin-agarose affinity chromatography (Laplaud et al. 1991). Three factors corresponding to pure HDL (fraction I and II) and LDL (fraction III) particles were isolated, allowing us to determine their structural properties. Apolipoprotein A-I (MM $28 \mathrm{kDa})$ is the predominant protein in the HDL subfractions which, unlike in primates and rodents, does not contain apo E. However, HDL corresponding to fraction II contain a small amount of a protein which is unknown in other mammals and exhibits (as does human apo E) heparin-binding properties (Laplaud et al. 1991). This protein probably corresponds to $\beta 2$ glycoprotein I according to its MM (51 kDa), amphiphilicity and immunological reactivity. Additional work on the purification and determination of the amino acid sequence of this protein is in progress in our laboratory in order to identify more precisely its structural and metabolic roles (ligand for tissue LDL receptor?) in bovine species. With respect to LDL from calf lymph, we have shown the presence of apo B100 together with apo B48 in similar amounts, whereas lymph chylomicrons and lymph VLDL particles contain only apo B48 (Laplaud et al. 1990, 1991). These results provided the first evidence of the filtration of apo B100-containing LDL from the plasma compartment and its subsequent recycling into intestinal lymph by calf enterocytes.

\section{HEPATIC METABOLISM OF LIPIDS AND LIPOPROTEINS}

\section{Origins of hepatic long-chain fatty acids}

Hepatic de novo fatty acid synthesis in ruminant animals is generally very low compared with that in humans or in rodents. The pool of long-chain fatty acids (LCFA) in the liver is mainly derived from plasma non-esterified fatty acids (NEFA) mobilized from adipose 
tissues. As in many species, the hepatic uptake of NEFA and their activation to LCFA-CoA are driven efficiently by mass action. A second source of LCFA, which is of minor importance for the liver, is the hydrolysis of plasma triacylglycerols transported by apo B-containing lipoproteins. Direct evidence of hepatic lipolysis was provided by in vivo approaches. Although hepatic lipase ( $E C$ 3.1.1.3) activity is virtually lacking, net hepatic uptake of triacylglycerols from VLDL was reported in preruminant calves (Bauchart et al. 1989; Auboiron et al. 1995) and in dairy cows (Reid et al. 1979; Durand et al. 1992) that were given restricted feed intake or deprived of feed. This might be facilitated by the lipolytic activity of LPL in this organ; this is indicated in calves fitted with chronic catheters in the hepatic ressels which showed a specified peak of LPL activity in a main hepatic vein 2 min after heparin injection in the distal part of the portal vein (D. Bauchart, D. Durand and T. Olivecrona, unpublished results). Similar, earlier findings in perfused rat livers suggested that some of the LPL molecules produced and secreted in blood by extrahepatic tissues would leave the surface of the capillary endothelium and promote triacylglycerol hydrolysis at the surface of the hepatic sinusoids (Vilaro et al. 1988).

\section{Hepatic metabolism of long-chain fatty acids}

The major metabolic fates of LCFA-CoA in the liver are (1) esterification into triacylglycerols and, to a lesser extent, into phospholipids and cholesteryl esters, (2) complete oxidation to $\mathrm{CO}_{2}$ or incomplete oxidation which generates acetate (precursor for cholesterol synthesis) and ketone bodies. Numerous data from in vivo and in vitro experiments in young and adult ruminants have provided the evidence that secretion of triacylglycerols as part of VLDL particles by the liver is low compared with LCFA esterification or oxidation. Such metabolic characteristics favour the appearance of a fatty liver and ketosis. These metabolic disorders frequently appear during the periparturient period in high-producing dairy cows (for recent reviews, see Bruss, 1993; Grummer, 1993). These changes can reduce milk production below the genetic potential and alter health and reproductive efficiency. Hepatic esterification of LCFA into triacylglycerols increases in the period 2 weeks before to 3 weeks after parturition in conjunction with a gradual increase in plasma concentrations of NEFA and a decrease in DM intake. Such metabolic variations might be partially favoured by changes in the hormonal status of the cows during this transition period (increases in both oestrogen and adrenaline, decrease in progesterone; Grummer, 1993).

Development of fatty liver in high-producing dairy cows is mainly related to the low capacity of the organ to export triacylglycerols as VLDL. In vitro studies using hepatocytes in culture clearly showed that triacylglycerol synthesis was similar in rats and in bovines. However, the rate of triacylglycerol secretion by goat hepatocytes was twenty-five times lower than that by rat hepatocytes (Kleppe et al. 1988). Hepatic balance measurements in cows in early lactation confirmed the in vitro results. Also, they indicated that a net but slight increase in triacylglycerol or VLDL output occurred in fed cows (Reid et al. 1979) and fed cows given supplements of limiting amino acids (methionine and lysine) by intravenous portal infusion (Durand et al. 1992). Similar results were recently obtained in the preruminant calf given methionine orally in energy-restricted or in normal feeding conditions (Auboiron et al. 1995). 


\section{Rate-limiting steps of hepatic synthesis and secretion of VLDL}

The successive steps of hepatic VLDL processing (lipid and apolipoprotein synthesis, particle packaging) and secretion (intracellular transport, maturation and incorporation of particles into secretion vesicles) are considered to be similar among mammalian species. On the other hand, the rate-limiting steps in VLDL export from the liver of the ruminant are still not clearly identified. Since no accumulation of nascent VLDL particles in the secretory Golgi vesicles was observed in hepatocytes of cows or of fed calves, either untreated or treated with orotic acid (inhibitor of VLDL secretion in rodents; Bauchart, 1993). Biosynthesis and availability of VLDL constituents (triacylglycerols, apoproteins, phospholipids) for VLDL packaging are more likely to be affected than the secretory processes.

The existence of two hepatic pools of triacylglycerols, a large cytoplasmic storage pool and a small microsomal secretory pool, was suggested from studies in sheep following intravenous infusion of radiolabelled LCFA (Pullen et al. 1988). As in rats (Gibbons, 1990), dietary conditions that enhanced de novo LCFA synthesis in hepatocytes favoured the secretory pool and, therefore, VLDL output. By contrast, the high rate of exogenous LCFA uptake increased the storage pool and favoured lipid infiltration of the liver. Therefore, the low capacity for LCFA synthesis together with the high rate of esterification of exogenous LCFA mobilized from fat stores in dairy cows during the periparturient period could explain in part the low capacity of the liver to secrete VLDL efficiently. A genetic defect in hepatic transport of stored triacylglycerols or in intracellular lipolysis of stored triacylglycerols by an hepatic lipase might occur in ruminant animals. This would be the result of low activities of cellular lipid transport proteins such as the microsomal triacylglycerol-transfer protein (MTP), the structural alteration of which induces lipid infiltration of the small intestine in humans (Wetterau et al. 1992). Alternatively, salt-resistant hepatic lipase activity may be low and ratelimiting in the bovine liver (Cordle et al. 1983).

Slow rates of apo B synthesis and incorporation into VLDL particles had been suggested also to explain the low VLDL output in ruminant animals (Bauchart, 1993; Grummer, 1993). Thus, reduction of plasma concentrations of apo B100, the largest form of apo B which is only synthesized by bovine liver (Greeve et al. 1993), was correlated with the induction of fatty liver by ethionine (inhibitor of protein synthesis) administered to cows (Uchida et al. 1992). The regulation of apo B100 hepatic gene expression in cows during the gestation-lactation cycle was studied recently by our group (Gruffat et al. 1995; D. Gruffat, D. Bauchart, D. Durand, J. C. Robert and Y. Chilliard, unpublished results). Simultaneous determinations of hepatic levels of apo B, apo B mRNA and triacylglycerols clearly showed a negative correlation between apo B gene expression and fatty liver development in the first week of lactation compared with the dry period or pregnancy. However, a stimulation of hepatic apo B synthesis by preand/or post-transcriptional regulation was observed during the first month of lactation. Nevertheless, such stimulation was unable to reduce lipid infiltration in cows in situations of negative energy balance. Conversely, in cows in positive energy balance during mid-lactation, the disappearance of hepatic steatosis was associated with a larger amount of apo B in hepatocytes. Since no modification in apo B mRNA level was noted at this stage, apo $B$ accumulation in hepatocytes might be the result of a higher rate of translation and/or decreased intracellular degradation of the protein. Factors implicated in these regulating processes, however, are still unknown. The biosynthesis and 
availability of phospholipids, the main constituents with apo B in the hydrophilic envelope of VLDL particles, can also regulate hepatic output of VLDL in ruminants. Intravenous infusions of methionine (Durand et al. 1992) and choline (Juslin, 1965), precursors for phosphatidylcholine synthesis, to lactating cows favoured hepatic VLDL secretion and reduced lipid infiltration respectively. However, the efficiency and safety of these components need to be investigated under normal conditions of feeding. Since these compounds are extensively degraded by rumen bacteria, dietary supplementation of these nutrients requires their encapsulation to protect against rumen fermentation.

\section{Influence of feeding fat on the hepatic metabolism of lipoproteins}

Increasing quantities of fat in diets increased plasma concentrations of VLDL in preruminant calves (Auboiron et al. 1994) and in dairy cows (Storry et al. 1980). Dietary fat stimulated hepatic secretion of VLDL in calves (Auboiron et al. 1995) but can favour lipid deposition in the liver. Thus, fat supplementation of diets given to cows from $17 \mathrm{~d}$ prepartum to $35 \mathrm{~d}$ post-partum tended to increase lipid infiltration of the liver after parturition when compared with the control cows (Skaar et al. 1989). This could be the result of a higher uptake of NEFA by the liver in feeding conditions that favoured NEFA release from adipose tissues (Grummer \& Carroll, 1991).

Data on the effects of dietary fatty acids on hepatic lipid and lipoprotein metabolism are scarce. Replacing soyabean oil (rich in linoleic acid) by tallow (rich in stearic and oleic acids) in milk substitutes for preruminant calves induced hypercholesterolaemia due to a specific increase in plasma concentrations of large HDL (type 1) rich in cholesteryl esters (Leplaix-Charlat et al. 1996b). Dietary linoleic acid favoured in vivo VLDL secretion by the liver but did not modify hepatic levels of apo B and apo B mRNA (Leplaix-Charlat et al. 1996a). However, such stimulation was not observed in goat hepatocytes incubated with media enriched with linoleic acid (Armentano et al. 1991). In calves fed on a soyabean-oil-rich diet, cholesteryl esters were preferentially incorporated into VLDL particles to the detriment of triacylglycerols which accumulated in the liver (Leplaix-Charlat et al. 1996a). Addition of cholesterol (10 g/kg diet DM) to tallow- or soyabean-oil-rich diets did not modify VLDL metabolism, but increased the plasma concentration of LDL, possibly by a negative effect on tissue LDL receptors and/or by the direct secretion of LDL-size particles by the liver (Leplaix-Charlat et al. 1996a,b). These findings indicate that in the young bovine, unlike rodents and primates, dietary linoleic acid does not reduce but favours the hypercholesterolaemic effect of dietary cholesterol.

\section{CONCLUSIONS}

The present paper constitutes a brief review on lipid and lipoprotein synthesis, and assembly, modification and secretion of lipoproteins by the small intestine and the liver in ruminants. While the major constituents of lipoproteins and their synthetic pathways are broadly understood, many aspects of the mechanisms involved in assembly and secretion of lipoproteins, especially VLDL, need clarification. For example, why do exogenous fatty acids enhance triacylglycerol export by enterocytes whereas they favour triacylglycerol storage in the cytoplasm of hepatocytes? In this respect, is the significant lipid infiltration of the liver in cows in early lactation facilitated by impaired gene expression of cellular triacylglycerol transport proteins and/or impaired lipolysis of 
stored triacylglycerols? Alternatively, is the apparently low contribution of apo B100 to VLDL formation in hepatocytes due to a down-regulation of apo B100 gene expression and/or a subsequent intracellular degradation of apo B100 in the smooth endoplasmic reticulum? These are only a few of the many important questions that need further investigation.

\section{REFERENCES}

Armentano, L. E., Grummer, R. R., Bertic, S. J., Skaar, T. C. \& Donkin, S. S. (1991). Effect of energy balance on hepatic capacity for oleate and propionate metabolism and triglyceride secretion. Journal of Dairy Science 74, 132-139.

Auboiron, S., Durand, D., Bauchart, D., Robert, J. C. \& Chapman, M. J. (1994). Lipoprotein metabolism in the preruminant calf: effect of a high fat diet supplemented with L-methionine. Journal of Dairy Science 77, $1870-1881$.

Auboiron, S., Durand, D., Robert, J. C., Chapman, M. J. \& Bauchart, D. (1995). Effect of dietary fat and $\mathrm{L}$-methionine on the hepatic metabolism of very low density lipoproteins in the preruminant calf, Bos spp. Reproduction Nutrition Development 35, 167-178.

Bauchart, D. (1983). Evolution avec l'âge de la cholestérolémie et de la triglycéridémie postprandiales chez le veau préruminant; influence de l'ingestion de sorbitol (Changes with age in postprandial cholesterolaemia and triglyceridaemia in the preruminant calf; influence of sorbitol intake). Reproduction Nutrition Development 23, 81-92.

Bauchart, D. (1993). Lipid absorption and transport in ruminants. Journal of Dairy Science 76, 3864-3881.

Bauchart, D., Doreau, M. \& Kindler, A. (1987). Effect of fat and lactose supplementation on digestion in dairy cows. 2. Long-chain fatty acids. Journal of Dairy Science 70, 71-80.

Bauchart, D., Durand, D., Laplaud, P. M., Forgez, P., Goulinet, S. \& Chapman, M. J. (1989). Plasma lipoproteins and apolipoproteins in the preruminant calf, Bos spp: density distribution, physicochemical properties, and the in vivo evaluation of the contribution of the liver to lipoprotein homeostasis. Journal of Lipid Research 30, 1499-1514.

Bauchart, D. \& Levieux, D. (1985). Lipoprotéines plasmatiques de veau préruminant (Plasma lipoproteins in the preruminant calf). Reproduction Nutrition Development 25, 243-250.

Bruss, M. L. (1993). Metabolic fatty liver of ruminants. Advances in Veterinary Science and Comparative Medicine 37, 417-449.

Clinquart, A., Micol, D., Brundseaux, C., Dufrasne, I. \& Istasse, L. (1995). Utilisation des matières grasses chez les bovins à l'engraissement (Fat utilization in growing-fattening bulls). INRA Productions Animales $8,29-42$.

Cordle, S. R., Yeaman, S. R. \& Clegg, R. A. (1983). Salt-resistant (hepatic) lipase; evidence for its presence in bovine liver and adrenal cortex. Biochimica et Biophysica Acta 753, 213-219.

Doreau, M., Ferlay, A., Elmeddah, Y. \& Bauchart, D. (1989). La 'protection' des matières grasses utilisées dans l'alimentation des ruminants: conséquences sur la digestion (Fat protection in diets for ruminants: consequences on digestion). Revue Française des Corps Gras 6, 271-278.

Durand, D., Bauchart, D., Laplaud, P. M., Lefraivre, J. \& Chapman, M. J. (1990). Importance of the portal venous pathway to the transport of intestinal triglyceride-rich lipoproteins in the preruminant calf. Reproduction Nutrition Development 30, Suppl. 2, 2285 Abstr.

Durand, D., Bauchart, D., Lefaivre, J. \& Donnat, J. P. (1988). Method for continuous measurement of blood metabolite hepatic balance in conscious preruminant calves. Journal of Dairy Science 71, 1632-1637.

Durand, D., Chilliard, Y. \& Bauchart, D. (1992). Effects of lysine and methionine on in vitro hepatic secretion of VLDL in the high yielding dairy cow. Journal of Dairy Science 75, Suppl., 279 Abstr.

Gibbons, G. F. (1990). Assembly and secretion of hepatic very-low density lipoproteins. A review article. Biochemical Journal 268, 1-13.

Greeve, J., Altkemper, I., Dieterich, J. H., Greten, H. \& Windler, E. (1993). Apolipoprotein B mRNA editing in 12 different mammalian species: hepatic expression is reflected in low concentrations of apo B-containing plasma lipoproteins. Journal of Lipid Research 34, 1367-1383.

Gruffat, D., Duboisset, F., Durand, D., Lefaivre, J., Ollier, A., D'Onofrio, G., Williams, P., Chilliard, Y. \& Bauchart, D. (1995). Hepatic apo B and $m$ RNA apo B levels in the underfed high-producing dairy cow during early lactation. Annales de Zootechnie 43, Suppl. 1, 47S-48S. 
Grummer, R. R. (1993). Etiology of lipid-related metabolic disorders in periparturient dairy cows. Journal of Dairy Science 76, 3882-3896.

Grummer, R. R. \& Carroll, D. J. (1991). Effect of dietary fat in metabolic disorders and reproductive performance of dairy cattle. Journal of Animal Science 69, 3838-3852.

Harrison, F. A., Leat, W. M. R. \& Forster, A. (1974). Absorption of maize oil infused into the duodenum of the sheep. Proceedings of the Nutrition Society 33, 101A-102A.

Juslin, K. E. (1965). On the effect of choline chloride on cyanocobalamine on the livers of cows with parturient paresis. Nordisk Veterinarmedicin 17, 169-175.

Kleppe, B. B., Aiello, R. J., Grummer, R. R. \& Armentano, L. E. (1988). Triglyceride accumulation and very-low density lipoprotein secretion by rat and goat hepatocytes in vitro. Journal of Dairy Science $\mathbf{7 1}$, 1813-1822.

Laplaud, P. M., Bauchart, D., Durand, D., Beaubatie, L. \& Chapman, M. J. (1991). Intestinal lymph and plasma lipoproteins in the preruminant calf: partial resolution of particle heterogeneity in the $1,040-1,090$ $\mathrm{g} / \mathrm{ml}$ interval. Journal of Lipid Research 32, 1429-1439.

Laplaud, P. M., Bauchart, D., Durand, D. \& Chapman, M. J. (1989). Intestinal lipoproteins in the preruminant calf: characterization of particle species and evidence for the portal vein as a major export pathway at peak lipid absorption. In Intestinal Lipid and Lipoprotein Metabolism, pp. 50-58 [E. Windler and H. Greten, editors]. München, Germany: Zuckschwerdt Verlag.

Laplaud, P. M., Bauchart, D., Durand, D. \& Chapman, M. J. (1990). Lipoproteins and apolipoproteins in intestinal lymph of the preruminant calf, Bos spp, at peak lipid absorption. Journal of Lipid Research 31, 1781-1792.

Leplaix-Charlat, L., Bauchart, D. \& Durand, D. (1996a). Effects of tallow- and soybean oil-containing diets with and without cholesterol on hepatic metabolism of lipids and lipoproteins in the preruminant calf, Bos spp. Journal of Dairy Science (In the Press).

Leplaix-Charlat, L., Bauchart, D., Durand, D., Laplaud, P. M. \& Chapman, M. J. (1996b). Plasma lipoproteins in preruminant calves fed diets containing tallow or soybean oil with and without cholesterol. Journal of Dairy Science (In the Press)

Moore, J. H. \& Christie, W. W. (1984). Digestion, absorption and transport of fats in ruminant animals. In Fats in Animal Nutrition, pp. 123-149 [J. Wiseman, editor]. London: Butterworths.

Palmquist, D. L. (1988). The feeding value of fats. In Feed Science, pp. 293-311 [E. R. Ørskov, editor]. Amsterdam: Elsevier Science Publishers B.V.

Palmquist, D. L. (1994). The role of dietary fats in efficiency of ruminants. Journal of Nutrition 124, $1377 \mathrm{~S}-1382 \mathrm{~S}$.

Pullen, D. S., Emery, R. S. \& Ames, N. K. (1988). Turnover of hepatic and plasma triacylglycerol in sheep. Journal of Animal Science 66, 1538-1547.

Reid, I. H., Collins, R. A., Baird, G. D., Roberts, C. J. \& Symonds, H. W. (1979). Lipid production rates and the pathogenesis of fatty liver in fasted cows. Journal of Agricultural Science, Cambridge 93, $253-256$.

Skaar, T. C., Grummer, R. R., Dentine, M. R. \& Stauffacher, R. H. (1989). Seasonal effects of pre- and postpartum fat and niacin feeding on lactation performance and lipid metabolism. Journal of Dairy Science 72, 2028-2038.

Storry, J. E., Brumby, P. E., Tuckley, B., Welch, V. A., Stead, D. \& Fulford, R. J. (1980). Effect of feeding protected lipid to dairy cows in early lactation on the composition of blood lipoproteins and secretion of fatty acids in milk. Journal of Agricultural Science, Cambridge 94, 503-516.

Uchida, E., Katoh, N. \& Tabahashi, K. (1992). Induction of fatty liver in cows by ethionine administration and concomitant decreases of serum apolipoproteins of B100 and A-I concentrations. American Journal of Veterinary Research 53, 2035-2042.

Vilaro, S., Llobera, M., Bengtsson-Olivecrona, G. \& Olivecrona, T. (1988). Lipoprotein lipase uptake by the liver: localization, turnover, and metabolic role. American Journal of Physiology 254, G711-G722.

Wetterall, J. R., Aggerbeck, L. P., Bouma, M. E., Eisenberg, C., Munck, A., Hermier, M., Schmitz, J., Gay, G., Rader, D. J. \& Gregg, R. E. (1992). Absence of microsomal triacylglyceride transfer protein in individuals with abetalipoproteinaemia. Science 258, 999-1001. 